\title{
Alpha-synuclein protofibrils in cerebrospinal fluid - a potential biomarker for Parkinson's disease
}

Marianne von Euler Chelpina, Linda Söderberg ${ }^{b}$, Johanna Fälting ${ }^{b}$, Christer Möller ${ }^{b}$, Marco Giorgettic, Radu Constantinescud ${ }^{d}$ Kaj Blennow ${ }^{a, e}$, Henrik Zetterberga,e,f,g and Kina Höglund ${ }^{a, e^{*}}$

a Department of Psychiatry and Neurochemistry, Institute of Neuroscience and Physiology, the Sahlgrenska Academy at the University of Gothenburg, Mölndal, Sweden

${ }^{\mathrm{b}}$ BioArctic AB, Warfvinges väg 35, 11251 Stockholm, Sweden

${ }^{c}$ AbbVie Inc., 1 N. Waukegan Road, North Chicago, IL 60064, USA

${ }^{\mathrm{d}}$ Department of Neurology, Sahlgrenska University Hospital, Göteborg, Sweden

e Clinical Neurochemistry Laboratory, Sahlgrenska University Hospital, Mölndal, Sweden

${ }^{\dagger}$ Department of Neurodegenerative Disease, UCL Institute of Neurology, Queen Square, London, UK

${ }^{g}$ UK Dementia Research Institute at UCL, London, UK

\section{Running title: $\alpha-s y n$ protofibrils-potential biomarker for PD}

${ }^{*}$ Correspondance to: Dr. Kina Höglund, Associate Professor. Department of Psychiatry and Neurochemistry, Institute of Neuroscience and Physiology, the Sahlgrenska Academy at the University of Gothenburg, House V3/SU, SE-431 80 Mölndal, Sweden. Tel: +46 763074975; E-mail: kina.hoglund@neuro.gu.se. 


\section{ABSTRACT}

Background: Currently, there is no established biomarker for Parkinson's disease (PD) and easily accessible biomarkers are crucial for developing disease-modifying treatments.

Objective: To develop a novel method to quantify cerebrospinal fluid (CSF) levels of $\alpha$-synuclein protofibrils ( $\alpha$-syn PF) and apply it to clinical cohorts of patients with PD and atypical parkinsonian disorders.

Methods: A cohort composed of 22 patients with progressive supranuclear palsy (PSP), 49 with PD, 12 with corticobasal degeneration (CBD) and 33 controls (CT), that visited the memory clinic but had no biomarker signs of Alzheimer's disease (AD, tau $<350 \mathrm{pg} / \mathrm{mL}$, amyloid-beta $42\left(\mathrm{~A} \beta_{42}\right)>530 \mathrm{pg} / \mathrm{mL}$ and phosphorylated tau $(\mathrm{p}$-tau $)<60$ $\mathrm{pg} / \mathrm{mL}$ ) was used in this study. The CSF samples were analyzed with the Single molecule array (Simoa) technology. Total $\alpha$-synuclein ( $\alpha$-syn) levels were analyzed with a commercial ELISA-kit.

Results: The assay is specific to $\alpha$-syn PF, with no cross-reactivity to monomeric $\alpha$ syn, or the $\beta$ - and $y$-synuclein variants. CSF $\alpha$-syn PF levels were increased in PD compared with controls (62.1 and $40.4 \mathrm{pg} / \mathrm{mL}$, respectively, $\mathrm{P}=0.02$ ), and CBD (62.1 and $34.2 \mathrm{pg} / \mathrm{mL}$, respectively, $P=0.01)$. The accuracy of predicting PD using $\alpha$-syn PF is significantly different from controls (area under the curve (AUC) $0.68, P=0.0097$ ) with a sensitivity of $62.8 \%$ and specificity of $67.7 \%$. Levels of total $\alpha$-syn were significantly different between the CBD group and PD group $(P=0.04)$, the CBD and $C T$ group $(P=$ $0.014)$ and between the PSP and CT groups $(P=0.023)$. 
Conclusion: The developed method specifically quantifies $\alpha$-syn PF in human CSF with increased concentrations in PD, but with an overlap with asymptomatic elderly controls.

Keywords: Parkinson's Disease, alpha-synuclein protofibrils, Simoa, biomarker, CSF, atypical parkinsonian disorders

\section{INTRODUCTION}

Parkinson's disease (PD) is the second most common neurodegenerative disease in the world with a significant unmet medical need. Worldwide, more than 4.6 million individuals over the age of 50 suffer from PD, and it is estimated that the number will more than double by the year 2030 [1]. The economic impact of the disease is enormous with millions of euros spent annually on symptomatic treatment [2, 3]. There is a huge need for treatments that slow or halt disease progression $[4,5]$. Improved patient outcomes could be achieved by early diagnosis and disease-modifying treatment. To this end, we developed and validated a novel quantitative PD biomarker assay that could be used to follow the underlying pathophysiology of the disease.

PD belongs to a large group of "parkinsonian disorders," where the main clinical symptoms are motor-related, manifested by resting tremor (specific for idiopathic PD), bradykinesia, rigidity and postural instability [6]. The primary motor characteristics of the disease are mainly due to the progressive degeneration of dopaminergic neurons in the substantia nigra (SN) and projections to the caudate and putamen, with subsequent decline in dopamine (DA) content [7]. Non-dopaminergic degeneration has also been reported on multiple sites in the PD-affected brain and is primarily linked to non-motor symptoms such as dementia, sleep disturbances, mood swings and severe 
anxiety $[8,9]$. The major component of Lewy bodies (LBs), the pathological hallmark of PD, is aggregated $\alpha$-syn [10], and studies on autopsy material from patients with PD suggest that LBs are formed prior to the appearance of motor symptoms [11]. In addition, point mutations and multiplications in the $\alpha$-syn gene have been linked to familial PD [12], and polymorphisms of the $\alpha$-syn promoter have been associated to increased risk of PD onset [13]. Increasing data suggest that the soluble oligomeric form of $\alpha$-syn is neurotoxic and may trigger neurodegeneration [14]. Together these data strengthen the association between protein-misfolding and disease, where $\alpha$-syn plays a key role. As a result, targeting $\alpha$-syn for the development of disease-modifying drugs is a promising approach for fighting PD. Currently, several immunotherapies for PD are in the early stages of clinical development. Some of the companies involved in the development of these therapies are AbbVie/BioArctic with ABBV-0805; Affiris with PD01A and PD03A; AstraZeneca with MEDI1341; BIOGEN with BIIB054/Cinpanemab; Lundbeck with Lu AF82422; ROCHE/PROTHENA with Prasinezumab; Neuropore/UCB with NPT200-11/UCB0599, among other [15].

The differential diagnosis of PD is based on clinical features, and the gold standard still remains neuropathological confirmation [16]. The detection of changes in $\alpha$-syn levels in CSF and blood of PD patients has been proposed as biomarker for diagnosis of disease and severity (reviewed in [17]). Several studies have been published evaluating monomeric $\alpha$-syn as a potential diagnostic biomarker and most studies point towards a slight overall decrease of $\alpha$-syn in CSF [18-20]. Other studies also suggest that $\alpha$-syn oligomers are increased in PD CSF [21-23]. A relatively new technique called protein misfolding cyclic amplification (PMCA) used to multiply minute quantities of prion proteins [24] has been standardized to detect $\alpha$-syn aggregates in various synucleinopathies, suggesting that $\alpha$-syn-PMCA may provide an efficient and non- 
invasive biochemical test for the diagnosis of PD [25]. Two recent studies applying the real-time quaking-induced conversion of $\alpha$-syn ( $\alpha$-syn RT-QuIC) have provided the first prototypes for ultrasensitive and specific detection of $\alpha$-syn aggregates in CSF of patients with PD and other synucleinopathies [26, 27].

The aggregated species of $\alpha$-syn can form oligomers and protofibrils (PF). Oligomers refer to smaller soluble aggregates that can be on the way of forming fibrils (onpathway) or fixed in a conformation that does not form fibrils (off-pathway) while PF are larger soluble multimeric species that always form fibrils [28, 29]. Measuring soluble aggregated proteins in the CSF of humans has been challenging due to the very low levels of the protein aggregates, which are thought to be in the femtomolar (fmol) range [30]. Most often, assay sensitivity is only good enough to measure aggregates in brain tissue or in various matrices from pre-clinical disease models, where the protein of interest many times is over-expressed, while levels in human CSF are at or near the detection limit [31]. Although studies have been published indicating CSF $\alpha$-syn as a potential diagnostic biomarker, these findings have not yet been clinically validated. Therefore, we have used an ultra-sensitive technology called Single molecule array (Simoa) [32] to develop and validate a method capable of quantifying levels of $\alpha$-syn PF in clinical cohorts of patients with PD and other parkinsonian disorders.

\section{MATERIALS AND METHODS}

Calibrator: recombinant $\alpha$-syn- $\alpha$-Syn PF (HNE-PF, BioArctic, Sweden) were used as calibrator [33]. Briefly, to produce aldehyde-induced $\alpha$-syn, HNE was added to the a-syn samples to a molar ratio of 30:1 HNE:a-syn. The samples were then incubated 
at $37^{\circ} \mathrm{C}$ for 18 hours, and unbound aldehyde was removed by a Zeba desalt spin column (Thermo Fisher Scientific, USA) equilibrated with $20 \mathrm{mM}$ Tris $\mathrm{pH}=7.4$ and 0.15 $\mathrm{M} \mathrm{NaCl}$. Ready-to-use calibrators were prepared with the highest calibration point at $3500 \mathrm{pg} / \mathrm{mL}$. Before each run, a 2-fold serial dilution down to $3.4 \mathrm{pg} / \mathrm{mL}$ (lowest calibration point) was performed.

Antibodies-The antibody rec38FII with high affinity and selectivity for a-syn PF (BioArctic, Sweden) [34] was used as capture antibody, and $\alpha / \beta$-synuclein antibody (F11, lot no. B1717, Santa Cruz Biotechnology, USA) was used as detection antibody (Table 1).

\section{Table 1}

Single molecule array (Simoa ${ }^{T M}$ )- Magnetic homebrew carboxylated beads (Quanterix, USA) were activated by adding $0.1 \mathrm{mg} / \mathrm{mL}$ of 1-ethyl-3-(3 dimethylaminopropyl)carbodiimide hydrochloride (EDC, Thermo Fisher Scientific, USA) to a bead solution with $1.4 \times 10^{6}$ beads $/ \mu \mathrm{L}$. After incubating at room temperature (RT) for 30 minutes $(\mathrm{min})$, the beads were washed in a magnetic separator and 0.2 $\mathrm{mg} / \mathrm{mL}$ of ice-cold capture antibody was added. The beads were incubated for 2 hours (hrs) on an agitator (HulaMixer, Invitrogen, USA) at $4{ }^{\circ} \mathrm{C}$. The beads were then washed and a blocking solution was added. After additional washes, the conjugated beads were re-suspended in corresponding bead diluent and stored at $4^{\circ} \mathrm{C}$ for future use. The monoclonal detection antibody F-11 $(200 \mu \mathrm{g} / \mathrm{mL})$ was biotinylated by adding a $40 \mathrm{X}$ biotin excess (EZ-Link ${ }^{\text {TM }}$ NHS-PEG4-Biotin, Thermo Fisher Scientific, USA) followed by 30 min incubation at RT. Free biotin was removed using an Amicon Ultra Centrifugal Filter (Millipore, Germany) and the biotinylated antibody was stored at $4^{\circ} \mathrm{C}$, as described in [35]. Human CSF samples and HNE-PF standard (240 $\mu \mathrm{L})$ were analyzed in duplicates in the Simoa HD-1 Analyzer (Quanterix, Lexington, MA). In short, the 
HNE-PF standard was diluted in assay diluent $\mathrm{pH}=9.0$ (50 mM Tris, $0.1 \%$ Tween, 5 mM EDTA, 2\% BSA) to construct the calibration curve (as described above). Samples and standard were plated on a 96-well plate (NUNC, Thermo Fisher Scientific, USA). The conjugated beads were washed 2 times in bead diluent buffer and then resuspended in the corresponding volume of bead diluent along with $10 \mu \mathrm{g} / \mathrm{mL}$ blocking solution (TruBlock ${ }^{\mathrm{TM}}$, Meridian Life Science, Inc., USA). The detector antibody was diluted in assay diluent $\mathrm{pH}=9.0$ to a final concentration of $0.3 \mu \mathrm{g} / \mathrm{mL}$ and the enzyme SBG (streptavidin $\beta$-galactosidase, Quanterix, USA) was diluted in SBG Diluent to a final concentration of $100 \mathrm{pM}$. Reagents, samples and calibrators were run in the HD1 Analyzer using a 3-step Assay Neat 2.0 protocol with $25 \mu \mathrm{L}$ conjugated beads, 100 $\mu \mathrm{L}$ biotinylated antibody, $100 \mu \mathrm{L}$ SBG and $25 \mu \mathrm{L}$ Resorufin $\beta$-D-galactopyranoside (RGP, Quanterix, Lexington, MA) [35].

Immunoassay for total a-syn in CSF- An enzyme-linked immunosorbent assay (ELISA) kit (catalog number: 844101, Legend Max, BioLegend, USA) was employed to measure total $\alpha$-syn levels in CSF samples. The analyses were performed as described by the manufacturer.

\section{Development and validation of Simoa a-syn PF assay}

The assay was performed using the conditions obtained from the optimization, technical qualification, and assay validation. The validation steps included: the establishment of the limit of detection (LOD) and lower limit of quantification (LLOQ), specificity, precision and accuracy, parallelism, dilution linearity, spike/recovery, and stability [36].

Assay sensitivity was determined by analyzing sixteen blank samples run in duplicates, and the LOD value was determined taking 2.5 SD above the blank. The LLOQ value was determined taking $10 \mathrm{SD}$ above the blank. 
The specificity for $\alpha$-syn aggregates was tested by cross-reactivity to monomeric $\alpha-, \beta$ and $\mathrm{\gamma}$-syn. Peptide concentrations up to $3500 \mathrm{pg} / \mathrm{mL}$ were tested. Additionally, one CSF sample was spiked with 2, 20, and $200 \mathrm{ng} / \mathrm{mL} \alpha$-syn monomers and analyzed.

To confirm that the signal was derived specifically from CSF a-syn PF levels, two representative CSF samples were immunodepleted using a cocktail of anti- $\alpha$-syn antibodies (Syn-1, BD Transduction Laboratories; rec38FII, BioArctic; MJFR14, Abcam and FL-140, Santa Cruz Biotechnology) according to the following protocol: protein $A+G$ beads were vortexed and transferred to new tubes. The beads were placed on a magnet for $1 \mathrm{~min}$, and the storage buffer was removed and the volume was recorded. The beads were washed by adding $500 \mu \mathrm{L}$ of $1 \%$ PBS-Tween, vortexed, spun and put on a magnet to remove supernatant. Beads were then resuspended in an equal volume of the storage buffer removed above. Antibodies or PBS (input control and protein A/G samples) were added to $1100 \mu \mathrm{L}$ of CSF spiked with Tween-20 to a final concentration of $0.05 \%$ and incubated on a RotaMix at RT. After $10 \mathrm{~min}$, protein $A+G$ beads were added to all samples (except input control) and incubated for another $40 \mathrm{~min}$. The samples were then spun shortly and placed on a magnet for 2 min and the supernatants from the depleted CSF samples were subjected to Simoa analysis alongside the non-depleted input CSF samples.

Precision and accuracy of the assay was determined using buffer spiked with recombinant $\alpha$-syn $\operatorname{PF}(\mathrm{QC} 1=3.7 \mathrm{pg} / \mathrm{mL}, \mathrm{QC2}=14.3 \mathrm{pg} / \mathrm{mL}, \mathrm{QC} 3=27.8 \mathrm{pg} / \mathrm{mL})$ and three individual human CSF samples (CSF1, CSF2, CSF3). Five duplicates of each of these samples were analyzed at four independent occasions. The intra-assay precision is presented as the mean $\mathrm{CVr}(\%)$, and the inter-assay precision is presented as the mean CVrw (\%). 
Parallelism was assessed using four individual CSF samples with varying concentrations of endogenous a-syn PF levels. The CSF samples were analyzed undiluted and after serial dilution 1:2, 1:4, 1:8, 1:16 and 1:32. Parallelism was evaluated by determining the mean back-calculated concentrations with a deviation at $\leq 20 \%$ as an indication of parallelism.

To test for dilution linearity, three human CSF samples and buffer were spiked with $700 \mathrm{pg} / \mathrm{mL}$ of $\alpha$-syn PF and serially diluted $1: 2,1: 4,1: 8,1: 16$, and 1:32. The interpolated value was multiplied by the dilution factor to obtain the initial $\alpha$-syn PF concentration.

a-Syn concentrations were measured in two CSF samples and buffer spiked with 7 $\mathrm{pg} / \mathrm{mL}, 70 \mathrm{pg} / \mathrm{mL}$ and $700 \mathrm{pg} / \mathrm{mL}$ of $\alpha$-syn PF. The concentration of the spiked samples and the endogenous concentration of the CSF samples were measured simultaneously. Recovery was calculated according to the following formula:

$$
\% \text { Recovery }=\frac{(\text { Measured conc. } \cdot \text { spiked sample })-(\text { Measured conc.neat sample })}{\text { Theoretical conc. } \cdot \text { spiked }} \times 100
$$

In order to test the stability of the a-syn PF at different storage conditions, ten fresh CSF samples were divided into thirty aliquots $(250 \mu \mathrm{L})$ and frozen according to the following scheme: 10 aliquots were stored at $-80^{\circ} \mathrm{C}$ for 2 months, 10 aliquots were stored at $-20^{\circ} \mathrm{C}$ for 2 months and the remaining 10 were stored at $-80^{\circ} \mathrm{C}$ for 1 month and then moved to $-20^{\circ} \mathrm{C}$ for another month.

\section{Clinical Study Populations}

A cohort composed of 22 patients with progressive supranuclear palsy (PSP), 49 with PD, 12 with corticobasal degeneration (CBD), and 33 age-matched non-PD controls 
(CT) was used in this study. The PD group was defined according to the clinical diagnostic criteria of the United Kingdom Parkinson's Disease Society Brain Bank [37]. The PSP group was defined according to the National Institute of Neurological Disorders and Stroke and the Society for Progressive Supranuclear Palsy, Inc. clinical criteria [38] and the CBD group was defined according to Lang et al. [39]. The control samples came from patients who had visited the memory clinic but had no biomarker signs of Alzheimer's disease (AD): tau< $350 \mathrm{pg} / \mathrm{mL}$, amyloid-beta $42\left(A \beta_{42}\right)>530 \mathrm{pg} / \mathrm{mL}$ and phosphorylated tau ( $\mathrm{p}$-tau) $<60 \mathrm{pg} / \mathrm{mL}$ (Swedish BioFINDER cohort). The descriptive details are presented in Table 2.

\section{Table 2}

Assays for tau, $p$-tau, $A \beta_{42}$, neurofilament light (NFL) and glial fibrillary acidic protein (GFAp)- The analyses were performed in routine tests at Sahlgrenska Univesity Hospital according to internal protocols.

Statistical Analyses- For statistical analyses, GraphPad Prism 8.1.0 and Stata/IC 15.1 were used. Since biomarker values did not follow a normal distribution, nonparametric tests were used. Differences among groups were evaluated using MannWhitney U-test and Kruskal-Wallis test. Statistical significance was set at $\mathrm{P} \leq 0.05$.

\section{RESULTS}

\section{Development of Simoa a-syn PF assay}

The assay, including antibody pair rec38FI//F-11, was optimized according to the scheme outlined in Figure 1.

Fig. 1 
After all the optimization steps were covered, the final assay conditions were selected (Table 3).

\section{Table 3}

\section{a-Syn PF assay validation}

The theoretical LOD value, determined taking 2.5 SD above the blank, was $0.65 \mathrm{pg} / \mathrm{mL}$ The concentration that corresponded to the LLOQ (10 SD above the blank) was 1.89 $\mathrm{pg} / \mathrm{mL}$. The upper limit of the curve was set to the highest calibrator point $(3500 \mathrm{pg} / \mathrm{mL})$. After running a numerous amount of native CSF samples, we found that the actual value for LLOQ corresponded to $6 \mathrm{pg} / \mathrm{mL}$ with an LOD of $1.9 \mathrm{pg} / \mathrm{mL}$. These numbers were obtained by introducing the signals from the native CSF samples and calibrator into a simulating software (SIMOA_4PL_Assay Developer Tool_February2018.xlsx, Quanterix, USA). For specific data, refer to Supplementary Fig. S1.

The specificity for $\alpha$-syn aggregates was tested by cross-reactivity tests to monomeric $\alpha-, \beta$ - and $\gamma$-syn. Peptide concentrations up to $3500 \mathrm{pg} / \mathrm{mL}$ were tested and did not result in detectable concentrations, confirming the specificity of the assay for $\alpha$-syn PF (Figure 2). Moreover, a CSF sample was spiked with 2, 20, and $200 \mathrm{ng} / \mathrm{mL}$ a-syn monomers and analyzed resulting in cross-reactivity of less than $0.006 \%$ for the highest spiking concentration.

\section{Fig. 2.}

To confirm that the signal derives from endogenous CSF $\alpha$-syn PF, two representative human PD CSF samples were immunodepleted using a cocktail of anti-a-syn antibodies (Syn-1, rec38FII, MJFR14 and FL-140) and the supernatants from the depleted CSF samples were subjected to Simoa analysis along-side the non-depleted 
input CSF samples. The CSF $\alpha$-syn PF levels were reduced to below LLOQ $(6 \mathrm{pg} / \mathrm{mL})$, suggesting a reduction of more than $80 \%$. As a control for non-specific bead reduction non-antibody coated beads were used (protein $A / G$ ) and signals obtained were similar to non-depleted CSF (Figure 3).

\section{Fig. 3}

Precision and accuracy of the assay was determined using buffer spiked with recombinant $\alpha$-syn PF $(\mathrm{QC} 1=3.7 \mathrm{pg} / \mathrm{mL}, \mathrm{QC} 2=14.3 \mathrm{pg} / \mathrm{mL}, \mathrm{QC} 3=27.8 \mathrm{pg} / \mathrm{mL})$ and three individual human CSF samples (CSF1, CSF2, CSF3). Overall, the intra-assay precision for QC samples and CSF samples was good, with CV values ranging between $3.9-9.4 \%$ and $8.8-17.2 \%$, respectively. The intermediate precision $\left(\mathrm{CV}_{\mathrm{rw}}\right)$ was within the accepted range for the QC samples with a mean CV of 11.7\% (10.2-13.0\%). However, for the CSF samples, the mean CV ranged between $23.4-34.4 \%$. Table 4 presents the precision and accuracy of the method for QC samples and human CSF.

\section{Table 4}

Parallelism was assessed using four individual CSF samples with varying concentrations of endogenous $\alpha$-syn PF levels. CSF samples were serially diluted 1:2, $1: 4,1: 8,1: 16$ and 1:32. Parallelism was evaluated by determining the mean adjusted concentrations and precision at $\leq 20 \%$ as an indication of parallelism. In three out of four CSF samples analyzed, parallelism was within accepted criteria for dilutions 2-fold from neat. For the higher dilutions, the endogenous signals measured were below assay LLOQ. These data suggest that CSF can be analyzed undiluted.

To test for dilution linearity, three human CSF samples and buffer were spiked with $700 \mathrm{pg} / \mathrm{mL}$ of $\alpha$-syn PF and serially diluted 1:2, 1:4, 1:8, 1:16, and 1:32. The interpolated value was multiplied by the dilution factor to obtain the initial $\alpha$-syn PF 
concentration. Results showed that the CSF samples did not follow linearity. However, the buffer spiked with $\alpha$-syn PF did follow linearity for all the dilutions (Figure 4).

\section{Fig. 4}

a-Syn concentrations were measured in two CSF samples and buffer spiked with 7 $\mathrm{pg} / \mathrm{mL}, 70 \mathrm{pg} / \mathrm{mL}$ and $700 \mathrm{pg} / \mathrm{mL} \alpha$-syn PF. The concentration of the spiked samples and the endogenous concentration of the CSF samples were measured simultaneously. After subtraction of the endogenous $\alpha$-syn concentration, the mean recovery was estimated to $71.4 \%$ (36.6-95.3\%) for the $7 \mathrm{pg} / \mathrm{mL}$ spike, to $79.1 \%(62.1$ $96.4 \%)$ for the $70 \mathrm{pg} / \mathrm{mL}$ spike and $72.3 \%$ (50.7-104.2\%) for the $700 \mathrm{pg} / \mathrm{mL}$ spike. The spike recovery in CSF was lower compared to buffer, as shown in Table 5.

\section{Table 5}

To evaluate the effect that storage conditions can have on the a-syn PF concentration, ten fresh CSF samples were stored at either $-80^{\circ} \mathrm{C}$ or $-20^{\circ} \mathrm{C}$ for two months. We show that the concentration of the CSF samples is generally higher at $-20^{\circ} \mathrm{C}$ suggesting that this could be the optimal storage condition for CSF samples (Figure 5).

\section{Fig. 5}

\section{Detection of $\alpha$-syn PF levels in clinical cohorts}

Having established that the rec38FII/F-11 Simoa PF assay is highly specific and can detect endogenous levels in most CSF samples, an evaluation of the diagnostic and prognostic value in a clinical cohort from the Sahlgrenska University Hospital was assessed. This cohort comprised samples from patients with CBD, PSP, and PD. The control samples came from patients who had visited the memory clinic but had no biomarker signs of Alzheimer's disease (AD) (tau<350 pg/mL, $A \beta_{42}>530 \mathrm{pg} / \mathrm{mL}$ and p- 
tau<60 pg/Ml). The CSF $\alpha$-syn PF levels had concentration values between 6 and 208 $\mathrm{pg} / \mathrm{mL}$, with only 2 samples below the assay LLOQ of $6 \mathrm{pg} / \mathrm{mL}$. In this cohort, we could find significant differences between the CBD group and PD group $(P=0.01)$ and the PD and CT group ( $P=0.02)$ for $\alpha$-syn PF (Fig. 6a). For total $\alpha$-syn, we could see significant differences between the CBD group and PD group $(P=0.04)$, the $C B D$ and CT group ( $P=0.014)$ and between the PSP and CT groups $(P=0.03)$ (Fig. 6b). Finally, the ratio between $\alpha$-syn PF and total $\alpha$-syn gave significant differences for the PD and CT group $(P=0.013)$ (Fig. 6c).

\section{Fig. 6}

Additional statistical analyses on this cohort showed differences among groups for several markers, including t-tau, $A \beta_{42}, p$-tau, NFL and GFAp. In general, the PD group showed lower concentrations of t-tau, p-tau, NFL and GFAp compared to the rest of the groups (Table 6).

\section{Table 6}

\section{DISCUSSION}

In this study, we used the Simoa technology to develop a method capable of quantifying CSF levels of $\alpha$-syn PF and applied on a clinical cohort of patients with PD and atypical parkinsonian disorders. We show that the assay is specific to $\alpha$-syn PF and has no crossreactivity with monomeric $\alpha$-syn or to $\beta$-syn and $\gamma$-syn. Several groups have reported an increase in oligomeric $\alpha$-syn in CSF of patients with PD [21-23, 40]; however, these groups report the increase measured in absorbance or relative luminescence units (RLU). To our knowledge, we are one of the first groups to report levels of $\alpha$-syn PF in concentration units $(\mathrm{pg} / \mathrm{mL})$. After thorough optimization of the assay, where introducing a wash step of beads prior to analyses improved the 
performance, we show that the concentration of $\alpha$-syn PF is increased in patients with PD compared with controls and CBD patients. We also show that our method can discriminate with relatively high accuracy between PD and non-PD subjects.

Although studies have been published indicating CSF $\alpha$-syn oligomers as a potential diagnostic biomarker, these findings have not yet been clinically validated. We have done a complete method validation to elucidate the efficacy of $\alpha$-syn PF as potential biomarkers for the diagnosis of PD. We show that the method has repeatability within the accepted range (below 15\% CV) and that CSF samples can be analyzed in a 2fold dilution from neat. We show that the intermediate precision for the CSF samples is $28.6 \% \mathrm{CV}$, which indicates that it is not optimal to run a study on different days. When recombinant PF were spiked into CSF samples, they do not follow linearity. However, when PF were spiked into the buffer, they follow linearity, suggesting a possible matrix effect in the CSF samples. Another explanation could be that the spiked PF are very different from endogenous a-syn aggregates present in human CSF samples, thereby explaining the lack of linearity when diluting. Additional confirmation of a possible matrix effect in the CSF samples is that the spike recovery is lower compared to spiked buffer samples. These findings highlight the challenge of measuring aggregated forms of $\alpha$-syn in CSF of humans.

Previous studies have failed to report limits of detection and quantification of the methods probably due to the very low levels of the protein aggregates in human CSF and/or to the lack of sensitivity of the assays. Using the Simoa technology, we were able to establish an LLOQ for the assay of $6 \mathrm{pg} / \mathrm{mL}$ and show that all CSF samples are quantifiable and above this limit. Another advantage of our assay is that we used a biotinylated detection antibody with an $\mathrm{N}$-terminal epitope in combination with a capture antibody with a C-terminal epitope that has a very high specificity and affinity 
for $\alpha$-syn PF and does not measure the monomeric form of the protein. This setup increases the probability of the detection antibody to bind to the analyte since there is no competition for the same binding site. Recently, Sehlin et al., confirmed that heterophilic antibodies (HA) present in human body fluids (that recognize antibodies from other species) might crosslink the capture antibody to the detection antibody and lead to false-positive signals in oligomer ELISA assay [41]. To avoid this, we added an HA blocker to the beads in a concentration of $10 \mu \mathrm{g} / \mathrm{mL}$.

A very important finding we made is that storage conditions can have a major impact on the concentration and/or stability of $\alpha$-syn PF. Therefore, thorough care must be taken when storing the samples avoiding thaw and freeze cycles.

Having established that the rec38FII/F-11 Simoa PF assay is highly specific and can detect endogenous levels in most CSF samples, we assessed the diagnostic and prognostic value in a clinical cohort. We show that there are significant differences between PD patients, controls, and CBD patients. By washing the beads before running the samples, we were able to get rid of the floating un-bound capture antibody that could be binding to the detector antibody and possibly avoiding false-positive signals.

Recently, two studies showed that the aggregated species of $\alpha$-syn could be measured in CSF with a sensitivity of $93 \%$ and specificity of $100 \%$ [27] and $92 \%$ sensitivity and 95\% specificity [26] using the RT-QulC technique. This method is able to discriminate between $\alpha$-synucleinopathies and non- $\alpha$-synucleinopathies. Our method has a sensitivity of $62.8 \%$ and specificity of $67.7 \%$ and it is also able to discriminate between PD and other atypical parkinsonian disorders. Numerous studies have been published evaluating monomeric $\alpha$-syn as a potential diagnostic biomarker and most studies point 
towards an overall decrease of $\alpha$-syn in CSF [18-20]. We show that there is a trend to a decrease in the concentration of total monomeric $\alpha$-syn in CSF of patients with PD. We also observed an increase in the ratio between $\alpha$-syn PF and total $\alpha$-syn for the PD group compared with controls. Mollenhauer et al. have reported a decrease in $A \beta_{42}$ levels for patients with PD compared with controls [42]. This is confirmed in our study, where there is a significant decrease in the concentration of $A \beta_{42}$ in the PD group. We report that the levels of t-tau and p-tau are significantly lower for the PD group compared with the control group. This finding has previously been reported by Hall et al. [43]. Several publications have reported that there are no significant differences in the levels of NFL in CSF between controls and PD [43-45]. However, we see that the control group has significantly higher levels of NFL than the PD group. An explanation for this could be that there is a very large spreading in the control group with individuals having very low levels of NFL and others having very high levels of the protein which affects the mean value. It could be that the individuals with high levels of NFL might have an underlying pathology (different from AD) that is reflected in the increase in NFL.

In conclusion, in this study, we developed and validated a novel immunoassay that can quantify soluble $\alpha$-syn PF in human CSF. Analytically, the assay is both sensitive and specific. The developed method quantifies $\alpha$-syn PF in human CSF and CSF $\alpha$-syn PF concentrations are increased in PD, but with an overlap with asymptomatic elderly controls. However, further studies including non-related neurological disorders and other synucleinopathies, are needed to fully validate the use of $\alpha$-syn PF as a diagnostic biomarker. 


\section{ACKNOWLEDGMENTS}

We thank BioArctic $A B$ and AbbVie Inc. for providing the calibrators and antibodies for the study. We thank Victor Liman for his invaluable assistance during the Simoa analyses. The project was funded by BioArctic AB. M. von Euler Chelpin was awarded a grant from Åhlén-Stiftelsen (mA27/h17).

\section{CONFLICT OF INTERESTS}

The authors Linda Söderberg, Johanna Fälting and Christer Möller are employees at BioArctic AB and Marco Giorgetti is employee at AbbVie.

\section{SUPPLEMENTARY MATERIAL}

The supplementary material is available in the electronic version of this article.

\section{REFERENCES}

[1] Dorsey ER, Constantinescu R, Thompson JP, Biglan KM, Holloway RG, Kieburtz K, Marshall FJ, Ravina BM, Schifitto G, Siderowf A, Tanner CM (2007) Projected number of people with Parkinson disease in the most populous nations, 2005 through 2030. Neurology 68, 384-386.

[2] Maresova P, Klimova B, Novotny M, Kuca K (2016) Alzheimer's and Parkinson's Diseases: Expected Economic Impact on Europe-A Call for a Uniform European Strategy. J Alzheimers Dis 54, 1123-1133.

[3] Findley L, Aujla M, Bain PG, Baker M, Beech C, Bowman C, Holmes J, Kingdom WK, MacMahon DG, Peto V, Playfer JR (2003) Direct economic impact of Parkinson's disease: a research survey in the United Kingdom. Mov Disord 18, 1139-1145.

[4] von Euler Chelpin M, Vorup-Jensen T (2017) Targets and Mechanisms in 
Prevention of Parkinson's Disease through Immunomodulatory Treatments. Scand J Immunol 85, 321-330.

[5] Connolly BS, Lang AE (2014) Pharmacological treatment of Parkinson disease: a review. JAMA 311, 1670-1683.

[6] Jankovic J (2008) Parkinson's disease: clinical features and diagnosis. $J$ Neurol Neurosurg Psychiatry 79, 368-376.

[7] Eriksen JL, Wszolek Z, Petrucelli L (2005) Molecular pathogenesis of Parkinson disease. Arch Neurol 62, 353-357.

[8] Schapira AHV, Chaudhuri KR, Jenner P (2017) Non-motor features of Parkinson disease. Nat Rev Neurosci 18, 509.

[9] Pfeiffer RF (2016) Non-motor symptoms in Parkinson's disease. Parkinsonism Relat Disord 22 Suppl 1, S119-122.

[10] Spillantini MG, Schmidt ML, Lee VM, Trojanowski JQ, Jakes R, Goedert M (1997) Alpha-synuclein in Lewy bodies. Nature 388, 839-840.

[11] Braak H, Del Tredici K (2008) Invited Article: Nervous system pathology in sporadic Parkinson disease. Neurology 70, 1916-1925.

[12] Kruger R, Kuhn W, Muller T, Woitalla D, Graeber M, Kosel S, Przuntek H, Epplen JT, Schols L, Riess O (1998) Ala30Pro mutation in the gene encoding alpha-synuclein in Parkinson's disease. Nat Genet 18, 106-108.

[13] Mikkilineni S, Cantuti-Castelvetri I, Cahill CM, Balliedier A, Greig NH, Rogers JT (2012) The anticholinesterase phenserine and its enantiomer posiphen as 5'untranslated-region-directed translation blockers of the Parkinson's alpha synuclein expression. Parkinsons Dis 2012, 142372.

[14] Eller M, Williams DR (2011) alpha-Synuclein in Parkinson disease and other neurodegenerative disorders. Clin Chem Lab Med 49, 403-408. 
[15] McFarthing K, Simuni, T. (2019) Clinical Trial Highlights: Targeting AlphaSynuclein. Journal of Parkinson's Disease 9, 5-16.

[16] Kalia LV, Lang AE (2015) Parkinson's disease. Lancet 386, 896-912.

[17] Atik A, Stewart T, Zhang J (2016) Alpha-Synuclein as a Biomarker for Parkinson's Disease. Brain Pathol 26, 410-418.

[18] Kang JH, Irwin DJ, Chen-Plotkin AS, Siderowf A, Caspell C, Coffey CS, Waligorska T, Taylor P, Pan S, Frasier M, Marek K, Kieburtz K, Jennings D, Simuni T, Tanner CM, Singleton A, Toga AW, Chowdhury S, Mollenhauer B, Trojanowski JQ, Shaw LM, Parkinson's Progression Markers I (2013) Association of cerebrospinal fluid beta-amyloid 1-42, T-tau, P-tau181, and alpha-synuclein levels with clinical features of drug-naive patients with early Parkinson disease. JAMA Neurol 70, 1277-1287.

[19] Mollenhauer B, Cullen V, Kahn I, Krastins B, Outeiro TF, Pepivani I, Ng J, Schulz-Schaeffer W, Kretzschmar HA, McLean PJ, Trenkwalder C, Sarracino DA, Vonsattel JP, Locascio JJ, El-Agnaf OM, Schlossmacher MG (2008) Direct quantification of CSF alpha-synuclein by ELISA and first cross-sectional study in patients with neurodegeneration. Exp Neurol 213, 315-325.

[20] Noguchi-Shinohara M, Tokuda T, Yoshita M, Kasai T, Ono K, Nakagawa M, El-Agnaf OM, Yamada M (2009) CSF alpha-synuclein levels in dementia with Lewy bodies and Alzheimer's disease. Brain Res 1251, 1-6.

[21] Hansson O, Hall S, Ohrfelt A, Zetterberg H, Blennow K, Minthon L, Nagga K, Londos E, Varghese S, Majbour NK, Al-Hayani A, El-Agnaf OM (2014) Levels of cerebrospinal fluid alpha-synuclein oligomers are increased in Parkinson's disease with dementia and dementia with Lewy bodies compared to Alzheimer's disease. Alzheimers Res Ther 6, 25. 
[22] Park MJ, Cheon SM, Bae HR, Kim SH, Kim JW (2011) Elevated levels of alpha-synuclein oligomer in the cerebrospinal fluid of drug-naive patients with Parkinson's disease. J Clin Neurol 7, 215-222.

[23] Tokuda T, Qureshi MM, Ardah MT, Varghese S, Shehab SA, Kasai T, Ishigami N, Tamaoka A, Nakagawa M, El-Agnaf OM (2010) Detection of elevated levels of alpha-synuclein oligomers in CSF from patients with Parkinson disease. Neurology 75, 1766-1772.

[24] Saborio GP, Permanne B, Soto C (2001) Sensitive detection of pathological prion protein by cyclic amplification of protein misfolding. Nature 411, 810-813.

[25] Shahnawaz M, Tokuda T, Waragai M, Mendez N, Ishii R, Trenkwalder C, Mollenhauer B, Soto C (2017) Development of a Biochemical Diagnosis of Parkinson Disease by Detection of alpha-Synuclein Misfolded Aggregates in Cerebrospinal Fluid. JAMA Neuro/ 74, 163-172.

[26] Fairfoul G, McGuire LI, Pal S, Ironside JW, Neumann J, Christie S, Joachim C, Esiri M, Evetts SG, Rolinski M, Baig F, Ruffmann C, Wade-Martins R, Hu MT, Parkkinen L, Green AJ (2016) Alpha-synuclein RT-QuIC in the CSF of patients with alpha-synucleinopathies. Ann Clin Transl Neurol 3, 812-818.

[27] Groveman BR, Orru CD, Hughson AG, Raymond LD, Zanusso G, Ghetti B, Campbell KJ, Safar J, Galasko D, Caughey B (2018) Rapid and ultra-sensitive quantitation of disease-associated alpha-synuclein seeds in brain and cerebrospinal fluid by alphaSyn RT-QuIC. Acta Neuropathol Commun 6, 7.

[28] Volles MJ, Lee SJ, Rochet JC, Shtilerman MD, Ding TT, Kessler JC, Lansbury PT, Jr. (2001) Vesicle permeabilization by protofibrillar alpha-synuclein: implications for the pathogenesis and treatment of Parkinson's disease. Biochemistry 40, 7812-7819. 
[29] Cole NB, Murphy DD, Lebowitz J, Di Noto L, Levine RL, Nussbaum RL (2005) Metal-catalyzed oxidation of alpha-synuclein: helping to define the relationship between oligomers, protofibrils, and filaments. J Biol Chem 280, 9678-9690.

[30] Wilson DH, Rissin DM, Kan CW, Fournier DR, Piech T, Campbell TG, Meyer RE, Fishburn MW, Cabrera C, Patel PP, Frew E, Chen Y, Chang L, Ferrell EP, von Einem V, McGuigan W, Reinhardt M, Sayer H, Vielsack C, Duffy DC (2016) The Simoa HD-1 Analyzer: A Novel Fully Automated Digital Immunoassay Analyzer with Single-Molecule Sensitivity and Multiplexing. $J$ Lab Autom 21, 533-547.

[31] Tucker S, Moller C, Tegerstedt K, Lord A, Laudon H, Sjodahl J, Soderberg L, Spens E, Sahlin C, Waara ER, Satlin A, Gellerfors P, Osswald G, Lannfelt L (2015) The murine version of BAN2401 (mAb158) selectively reduces amyloid-beta protofibrils in brain and cerebrospinal fluid of tg-ArcSwe mice. $J$ Alzheimers Dis 43, 575-588.

[32] Rissin DM, Kan CW, Campbell TG, Howes SC, Fournier DR, Song L, Piech T, Patel PP, Chang L, Rivnak AJ, Ferrell EP, Randall JD, Provuncher GK, Walt DR, Duffy DC (2010) Single-molecule enzyme-linked immunosorbent assay detects serum proteins at subfemtomolar concentrations. Nat Biotechnol 28, 595-599.

[33] Nasstrom T, Fagerqvist T, Barbu M, Karlsson M, Nikolajeff F, Kasrayan A, Ekberg M, Lannfelt L, Ingelsson M, Bergstrom J (2011) The lipid peroxidation products 4-oxo-2-nonenal and 4-hydroxy-2-nonenal promote the formation of alpha-synuclein oligomers with distinct biochemical, morphological, and functional properties. Free Radic Biol Med 50, 428-437.

[34] Fagerqvist T, Lindstrom V, Nordstrom E, Lord A, Tucker SM, Su X, Sahlin C, 
Kasrayan A, Andersson J, Welander H, Nasstrom T, Holmquist M, Schell H, Kahle PJ, Kalimo H, Moller C, Gellerfors P, Lannfelt L, Bergstrom J, Ingelsson M (2013) Monoclonal antibodies selective for alpha-synuclein oligomers/protofibrils recognize brain pathology in Lewy body disorders and alpha-synuclein transgenic mice with the disease-causing A30P mutation. $J$ Neurochem 126, 131-144.

[35] Kuhle J, Barro C, Andreasson U, Derfuss T, Lindberg R, Sandelius A, Liman V, Norgren N, Blennow K, Zetterberg H (2016) Comparison of three analytical platforms for quantification of the neurofilament light chain in blood samples: ELISA, electrochemiluminescence immunoassay and Simoa. Clin Chem Lab Med 54, 1655-1661.

[36] Andreasson U, Perret-Liaudet A, van Waalwijk van Doorn LJ, Blennow K, Chiasserini D, Engelborghs S, Fladby T, Genc S, Kruse N, Kuiperij HB, Kulic L, Lewczuk P, Mollenhauer B, Mroczko B, Parnetti L, Vanmechelen E, Verbeek MM, Winblad B, Zetterberg H, Koel-Simmelink M, Teunissen CE (2015) A Practical Guide to Immunoassay Method Validation. Front Neurol 6, 179.

[37] Hughes AJ, Daniel SE, Kilford L, Lees AJ (1992) Accuracy of clinical diagnosis of idiopathic Parkinson's disease: a clinico-pathological study of 100 cases. $J$ Neurol Neurosurg Psychiatry 55, 181-184.

[38] Litvan I, Bhatia KP, Burn DJ, Goetz CG, Lang AE, McKeith I, Quinn N, Sethi KD, Shults C, Wenning GK, Movement Disorders Society Scientific Issues C (2003) Movement Disorders Society Scientific Issues Committee report: SIC Task Force appraisal of clinical diagnostic criteria for Parkinsonian disorders. Mov Disord 18, 467-486. 
[39] Lang AE RD, Bergeron C (1994) Cortico-basal ganglionic degeneration. Calne D, editor. Neurodegenerative diseases. Philadephia: WB Saunders, 877-894.

[40] Aasly JO, Johansen KK, Bronstad G, Waro BJ, Majbour NK, Varghese S, Alzahmi F, Paleologou KE, Amer DA, Al-Hayani A, El-Agnaf OM (2014) Elevated levels of cerebrospinal fluid alpha-synuclein oligomers in healthy asymptomatic LRRK2 mutation carriers. Front Aging Neurosci 6, 248.

[41] Sehlin D, Sollvander S, Paulie S, Brundin R, Ingelsson M, Lannfelt L, Pettersson FE, Englund H (2010) Interference from heterophilic antibodies in amyloid-beta oligomer ELISAs. J Alzheimers Dis 21, 1295-1301.

[42] Mollenhauer B, Trenkwalder C, von Ahsen N, Bibl M, Steinacker P, Brechlin P, Schindehuette J, Poser S, Wiltfang J, Otto M (2006) Beta-amlyoid 1-42 and tau-protein in cerebrospinal fluid of patients with Parkinson's disease dementia. Dement Geriatr Cogn Disord 22, 200-208.

[43] Hall S, Surova Y, Ohrfelt A, Zetterberg H, Lindqvist D, Hansson O (2015) CSF biomarkers and clinical progression of Parkinson disease. Neurology 84, 5763.

[44] Constantinescu R, Rosengren L, Johnels B, Zetterberg H, Holmberg B (2010) Consecutive analyses of cerebrospinal fluid axonal and glial markers in Parkinson's disease and atypical Parkinsonian disorders. Parkinsonism Relat Disord 16, 142-145.

[45] Bacioglu M, Maia LF, Preische O, Schelle J, Apel A, Kaeser SA, Schweighauser M, Eninger T, Lambert M, Pilotto A, Shimshek DR, Neumann U, Kahle PJ, Staufenbiel M, Neumann M, Maetzler W, Kuhle J, Jucker M (2016) Neurofilament Light Chain in Blood and CSF as Marker of Disease Progression in Mouse Models and in Neurodegenerative Diseases. Neuron 
91, 56-66. 


\section{TABLES}

\begin{tabular}{ccccc}
\hline Antibody & IgG subclass & Type & Epitope & Source and Cat. No. \\
\hline rec38FII & $\operatorname{lgG} 2 \mathrm{a}$ & Recombinant & $113-123$ & BioArctic, N/A \\
\hline F-11 & $\operatorname{lgG} 2 \mathrm{~b}$ & Mouse monoclonal & $2-24$ & Santa Cruz, sc-514908 \\
\hline
\end{tabular}

Table 1: Description of the antibodies used. 


\begin{tabular}{ccccc}
\hline & PSP $(\mathbf{n = 2 2})$ & PD $(\mathbf{n = 4 9 )}$ & CBD $(\mathbf{n = 1 2})$ & CT $(\mathbf{n = 3 3 )}$ \\
\hline Female & 11 & 16 & 7 & 12 \\
Male & 11 & 33 & 5 & 21 \\
Age & $65(52-78)$ & $60(27-87)$ & $64(46-75)$ & $70(37-86)$ \\
$\begin{array}{c}\text { Disease duration } \\
\text { (years) }\end{array}$ & $5.4(1-16)$ & $7.8(1-33)$ & $3.9(1-7)$ & NA \\
H\&Y Stage & $3.8(1-5)$ & $2.5(1-5)$ & $4.1(2-5)$ & NA \\
\hline
\end{tabular}

Table 2: Descriptive details of the patient population used in this study. PSP: progressive supranuclear palsy; PD: Parkinson's disease; CBD: corticobasal degeneration; CT: Controls; H\&Y Stage: Hoehn-Yahr Stage. 


\begin{tabular}{|l|}
\hline Assay conditions for rec38FII/F-11 $\alpha$-syn PF Simoa assay \\
\hline Antibody conjugation concentration: $0.2 \mathrm{mg} / \mathrm{mL}$ \\
\hline EDC concentration: $0.1 \mathrm{mg} / \mathrm{mL}$ \\
\hline Biotin excess: $40 \mathrm{x}$ \\
\hline 3-step protocol \\
\hline Assay buffer: Tris buffer $\mathrm{pH}: 9.0$ \\
\hline Detector concentration: $0.3 \mu \mathrm{g} / \mathrm{mL}$ \\
\hline SBG concentration: $100 \mathrm{pM}$ \\
\hline No helper beads \\
\hline Incubation times: $40: 7: 7$ cadences $(30: 5.25: 5.25 \mathrm{~min})$ \\
\hline Sample volume: $100 \mu \mathrm{L}$ \\
\hline
\end{tabular}

Table 3: Assay conditions for rec38F/F-11 Simoa PF assay. SBG: Streptavidin $\beta$-galactosidase; EDC: 1-ethyl-3-(3 dimethylaminopropyl)carbodiimide hydrochloride. 


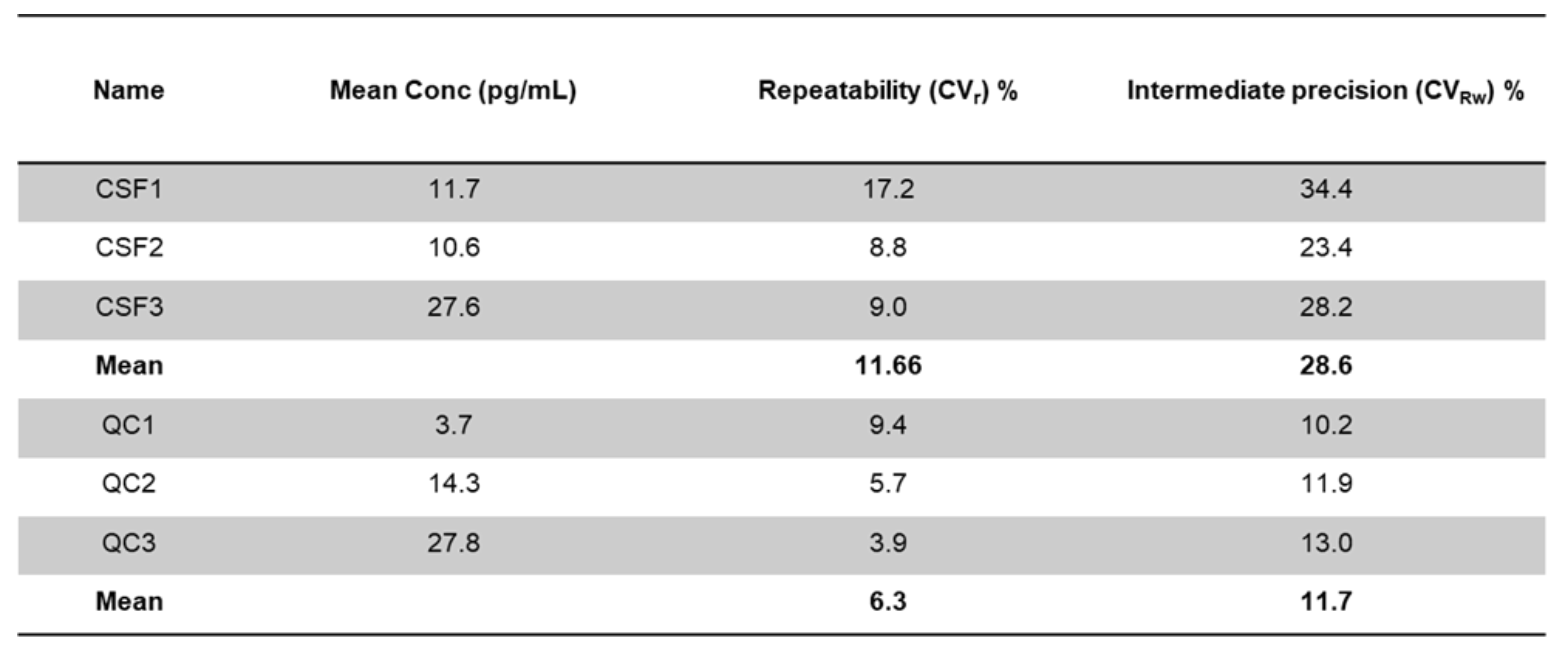

Table 4: Precision and accuracy for CSF and QC samples. Repeatability $\left(\mathrm{CV}_{\mathrm{r}}\right)$ : Variation between duplicates; Intermediate presicion $\left(\mathrm{CV}_{\mathrm{Rw}}\right)$ : Variation between runs. 


\begin{tabular}{|cccc|}
\hline $\begin{array}{c}\text { Spike } \\
\text { (pg/mL) }\end{array}$ & 7 & 70 & 700 \\
\hline Name & \multicolumn{4}{c|}{ Recovery (\%) } \\
\hline CSF1 & 95 & 79 & 51 \\
\hline CSF2 & 37 & 62 & 62 \\
\hline Buffer & 82 & 96 & 104 \\
\hline Mean & $\mathbf{7 1}$ & $\mathbf{7 9}$ & $\mathbf{7 2}$ \\
\hline
\end{tabular}

Table 5: Spike recovery of CSF samples compared with buffer spiked with 7,70 and $700 \mathrm{pg} / \mathrm{mL}$ of $\alpha$ syn PF. 


\begin{tabular}{|c|c|c|c|c|c|}
\hline & PSP (n=22) & $P D(n=48)$ & CBD (n=12) & $C T(n=33)$ & P-values \\
\hline Female & 11 & 15 & 7 & 12 & \multirow{2}{*}{0.384} \\
\hline Male & 11 & 33 & 5 & 21 & \\
\hline Age & 65 (52-78) & $60(27-87)$ & $64(46-75)$ & $70(37-86)$ & $0.003^{\star \star}$ \\
\hline Disease dur. & $5.4(1-16)$ & $7.8(1-33)$ & $3.9(1-7)$ & NA & 0.303 \\
\hline H\&Y Stage & $3.8(1-5)$ & $2.5(1-5)$ & $4.1(2-5)$ & NA & $0.0001^{\star \star \star *}$ \\
\hline $\begin{array}{l}\text { t-asyn } \\
(\mathrm{pg} / \mathrm{mL})\end{array}$ & $\begin{array}{c}1435(758- \\
3666)\end{array}$ & $1251(46-2571)$ & $984(443-1625)$ & $\begin{array}{c}1557(685- \\
4462)\end{array}$ & 0.121 \\
\hline $\begin{array}{l}\text { asyn PF } \\
(\mathrm{pg} / \mathrm{mL})\end{array}$ & $60.3(13.8-209)$ & $\begin{array}{c}62.1(20.3- \\
211.5)\end{array}$ & $34.2(16-81)$ & $\begin{array}{c}40.4(8.72- \\
187)\end{array}$ & $0.0153^{\star}$ \\
\hline $\begin{array}{c}\text { asyn PF/t- } \\
\text { asyn (\%) }\end{array}$ & $4.7(0.79-19.7)$ & $5.31(0.97-13.9)$ & $3.3(1.2-7.5)$ & $\begin{array}{c}3.02(0.36- \\
7.84)\end{array}$ & 0.091 \\
\hline t-tau (pg/mL) & $259(150-363)$ & $176.2(90-382)$ & NA & $\begin{array}{c}291(92- \\
854)\end{array}$ & $0.0004^{\star \star \star}$ \\
\hline $\begin{array}{c}\mathrm{p} \text {-tau } \\
(\mathrm{pg} / \mathrm{mL})\end{array}$ & $40.2(32-48)$ & $32.24(18-57)$ & NA & $48(23-110)$ & $0.0002^{\star \star \star}$ \\
\hline $\begin{array}{c}\mathrm{A} \beta_{1-42} \\
(\mathrm{pg} / \mathrm{mL})\end{array}$ & $586(270-958)$ & $555(300-940)$ & $490(160-851)$ & $\begin{array}{c}846(445- \\
1420)\end{array}$ & $0.0001^{\star \star \star}$ \\
\hline NFL (pg/mL) & $\begin{array}{c}1340(340- \\
2690)\end{array}$ & $\begin{array}{c}472.4(250- \\
1410)\end{array}$ & NA & $\begin{array}{c}1589(220- \\
6440)\end{array}$ & $0.0001^{\star \star \star}$ \\
\hline $\begin{array}{l}\text { GFAp } \\
\text { (pg/mL) }\end{array}$ & $806(380-1190)$ & $477(100-1270)$ & NA & NA & $0.037^{\star}$ \\
\hline
\end{tabular}

Table 6: Properties of the Sahlgrenska University Hospital cohort including levels of several markers for neurodegeneration. t-asyn: total $\alpha$-synuclein; asyn PF: $\alpha$-synuclein protofibrils; asyn PF/t-asyn: ratio between protofibrilar and total $\alpha$-synuclein; t-tau: total tau; $p$-tau: phosphorylated tau; $A \beta_{1-42}$ : amyloid-beta 1-42; NFL: neurofilament light; GFAp: glial fibrillary acidic protein. Statistical significance was achieved using a Kruskal-Wallis analysis. 


\section{FIGURES}

Figure 1

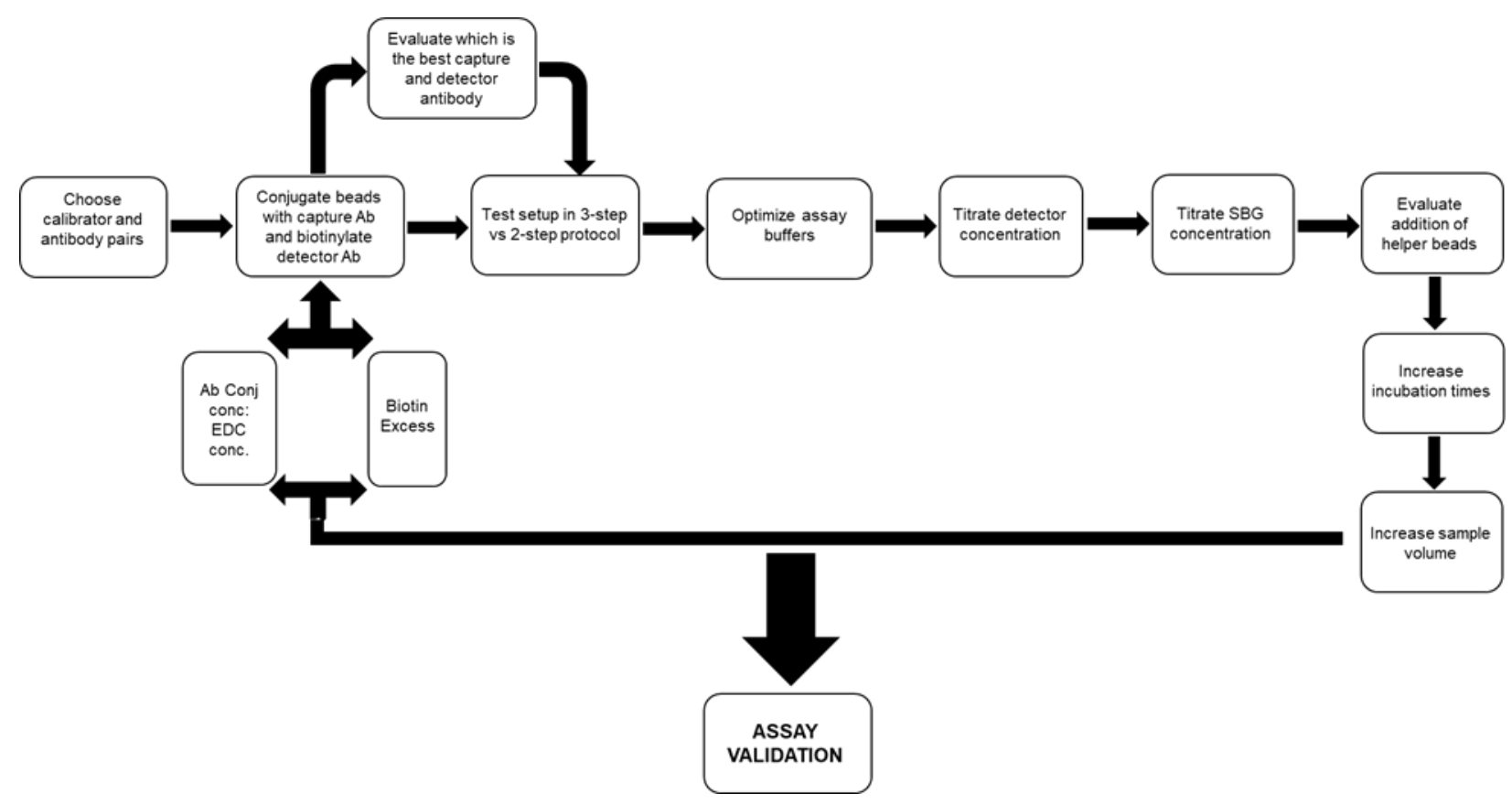


Figure 2

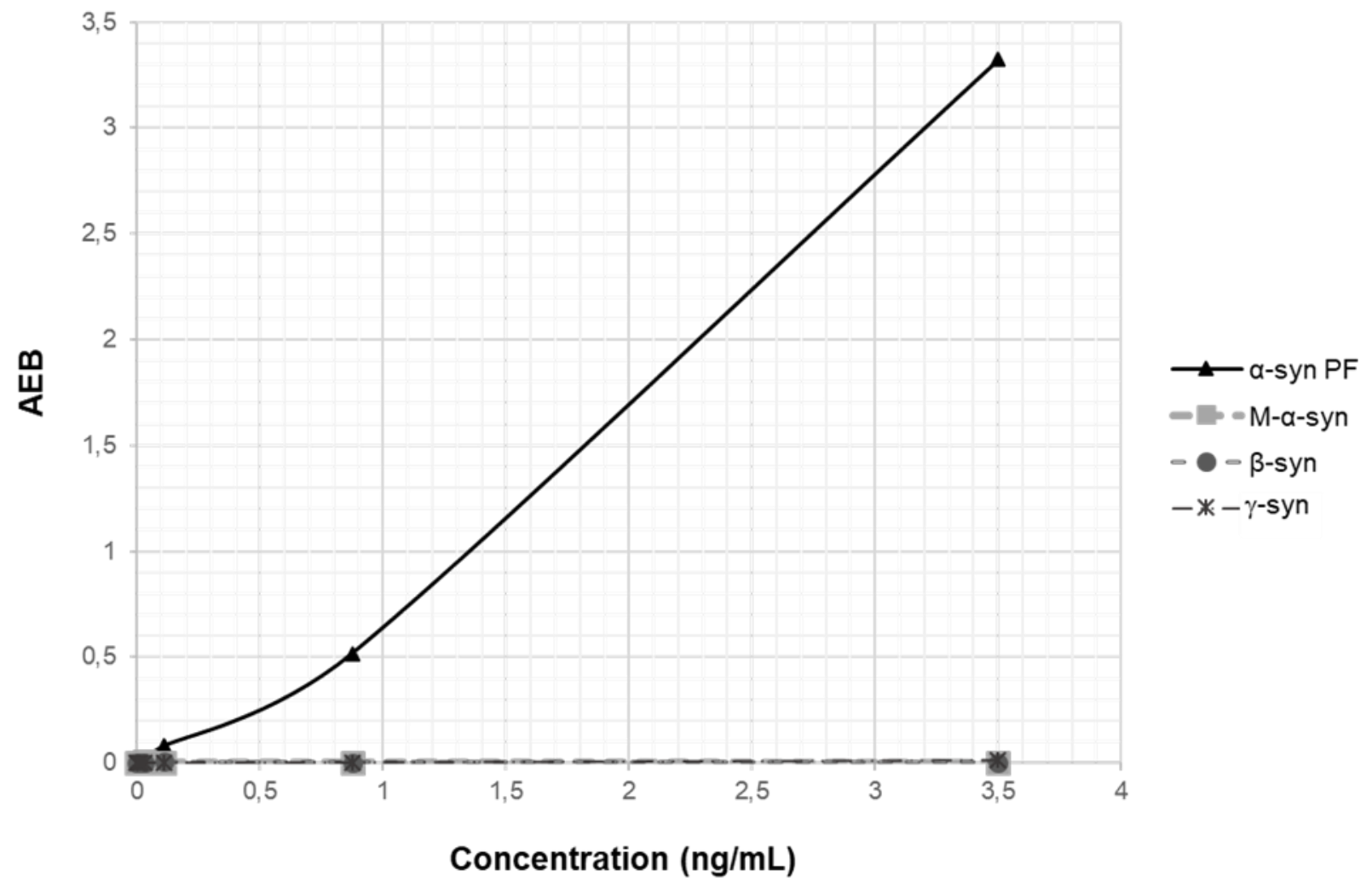


Figure 3

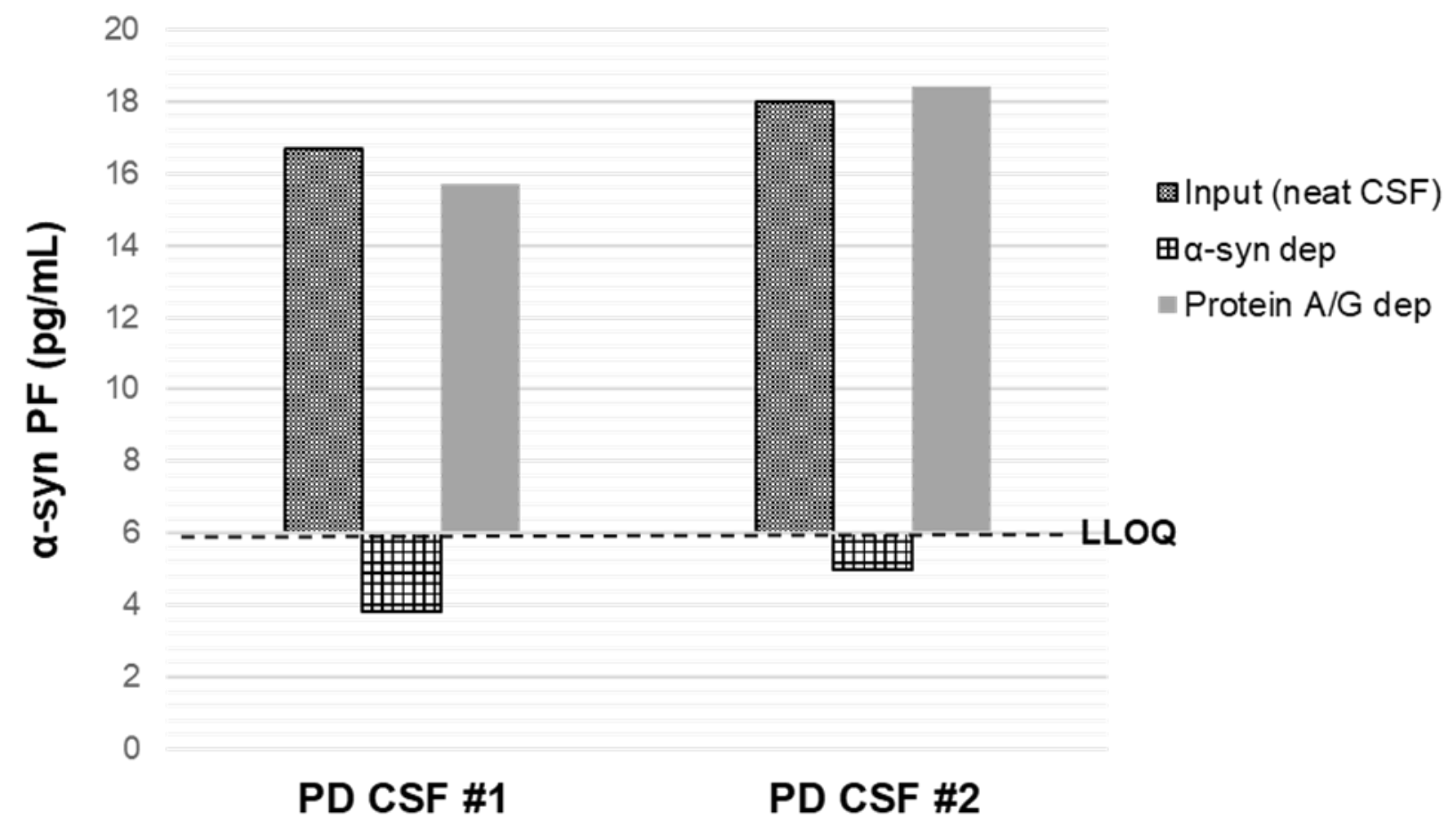


Figure 4

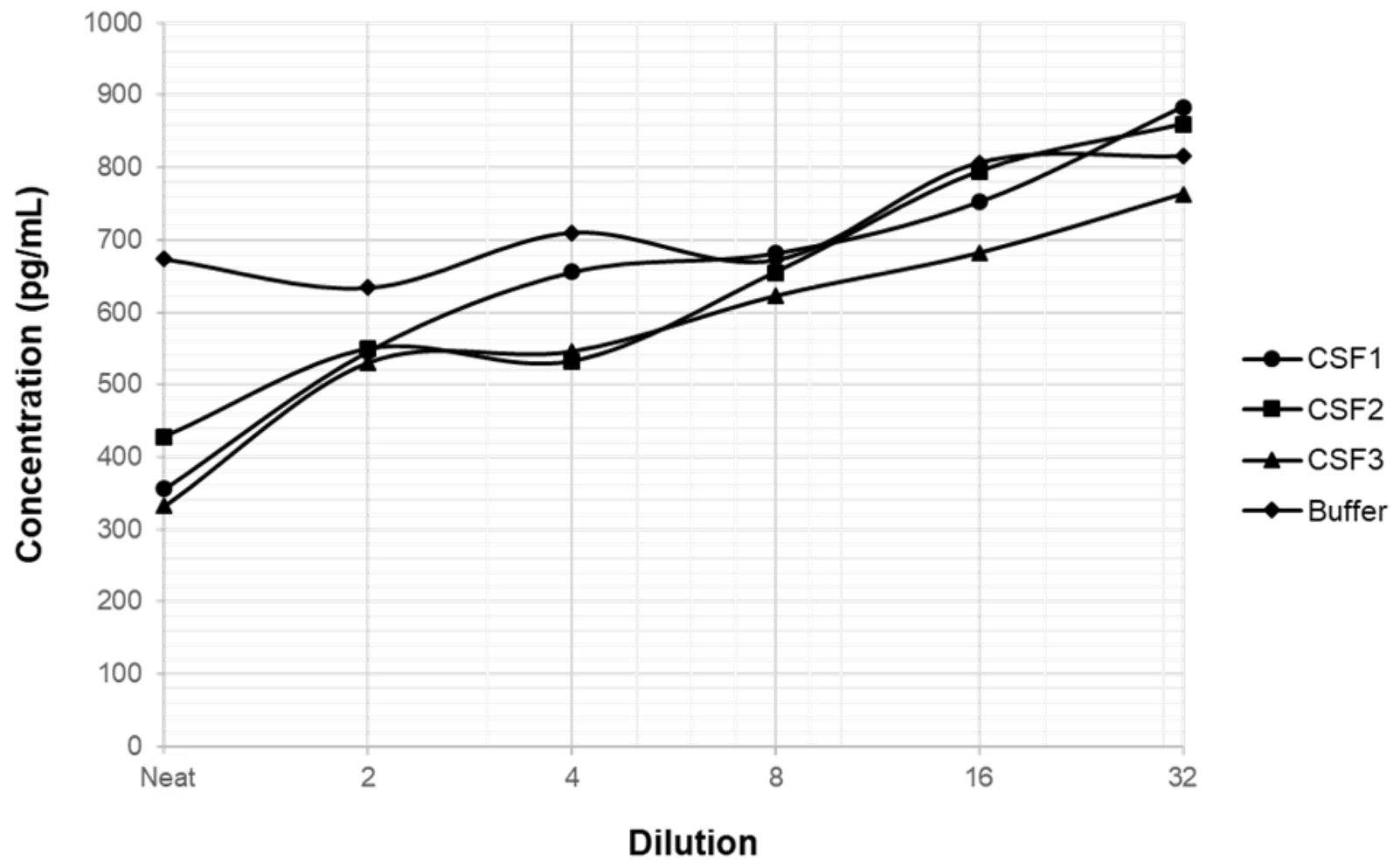




\section{Figure 5}

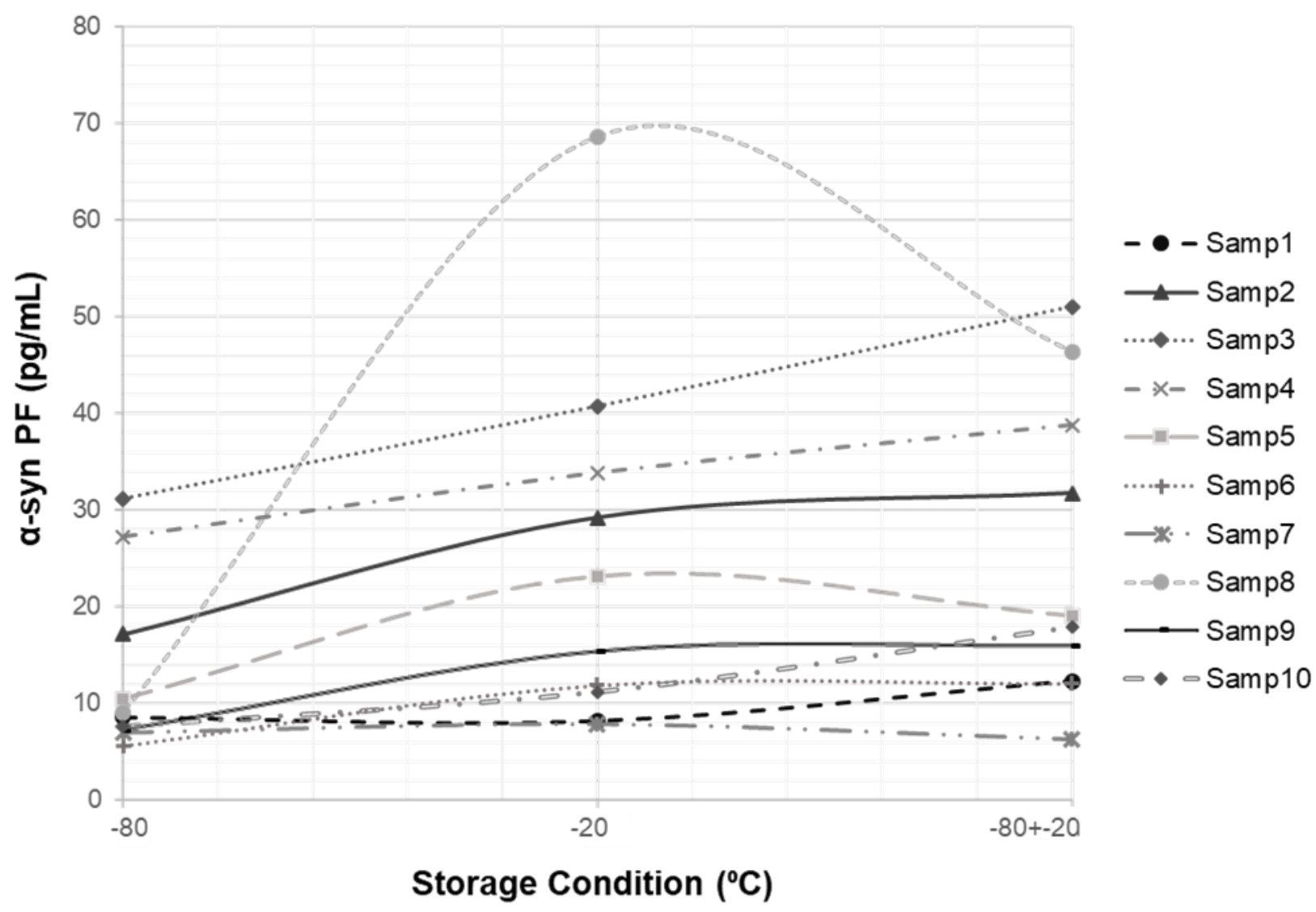


Figure 6
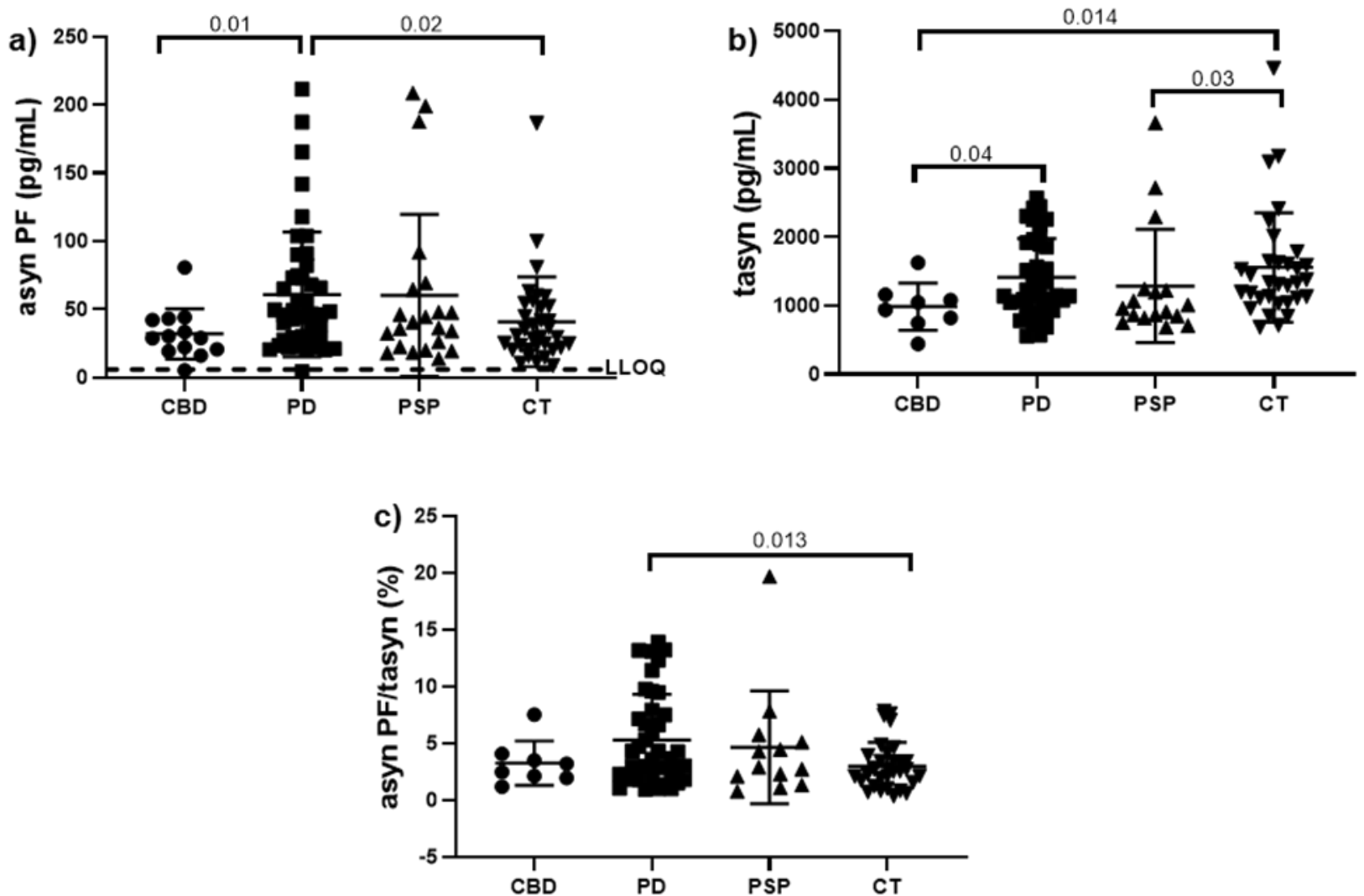


\section{FIGURE LEGENDS}

Figure 1: Schematic representation of the steps followed during the development of the Simoa assay. SBG: Streptavidin $\beta$-galactosidase; EDC: 1 -ethyl3-(3 dimethylaminopropyl)carbodiimide hydrochloride.

Figure 2: Specificity test of the assay. Cross-reactivity to monomeric $\alpha-, \beta$ - and $\gamma^{-}$ syn was assessed in concentrations up to $3500 \mathrm{pg} / \mathrm{mL}(0,3.4,6.8,13.7,27.3,109$, 875 and $3500 \mathrm{pg} / \mathrm{mL}$ ). $\alpha$-syn PF: $\alpha$-synuclein protofiblis (calibrator); M- $\alpha$-syn: monomeric $\alpha$-synuclein; $\beta$-syn: $\beta$-synuclein; $\gamma$-syn: $\gamma$-synuclein; AEB: average enzyme per bead.

Figure 3: Immunodepletion of PD CSF samples with anti-a-syn antibodies. Two CSF samples were immunoprecipitated using anti- $\alpha$-syn antibodies and the supernatants from the depleted CSF samples were subjected to Simoa analysis alongside the non-depleted (input) CSF samples. As control for non-specific bead reduction

non-antibody coated beads were used (protein A/G beads). A-syn PF: $\alpha$-synuclein protofibrils; $\alpha$-syn dep: $\alpha$-synuclein depletion; Protein A/G dep: protein $A / G$ depletion. LLOQ: lower level of quantification

Figure 4: Dilution linearity of serially diluted CSF samples after spiking with a high concentration of $\alpha$-syn PF. The graph shows the linearity of three CSF samples spiked with $700 \mathrm{pg} / \mathrm{mL} \alpha$-syn PF compared with a buffer solution spiked with the same amount of PF. Neat: Spiked undiluted sample.

Figure 5: Graph showing the $\alpha$-syn PF concentration at different storage conditions. $\alpha$-syn PF: $\alpha$-synuclein protofibrils; Samp\#: sample number. 
Figure 6: CSF $\alpha$-syn concentrations in normal and different neurological disease subjects from the Sahlgrenska University Hospital cohort analyzed neat in duplicates. a) Levels of $\alpha$-synPF. b) Concentrations of total $\alpha$-syn. c) Ratios between $\alpha$-syn PF and total $\alpha$-syn. Bars indicate mean with SD. Dashed line represents the lower limit of quantification (LLOQ) for the assay $(6 \mathrm{pg} / \mathrm{mL})$. Samples below the LOD and samples with $C V>20 \%$ were removed from the graph. PSP (progressive supranuclear palsy) $n=22$; PD (Parkinson's disease) $n=49$; CBD (corticobasal degeneration) $n=12$; CT (control group, age- and gender-matched to the PD group) $\mathrm{n}=33$. Statistical significance was achieved using a Mann-Whitney U-test. 


\section{SUPPLEMENTARY MATERIAL}

Supplementary Fig. S1: a) Table representing the real values for LOD and LLOQ for the assay after running several native CSF samples. b) Calibration curve with native CSF samples represented in orange. Dotted lines represent LLOQ and ULOQ. Orange dotted line represents the top concentration calculated for the assay. ULOQ: upper level of quantification.

a)
\begin{tabular}{|l|c|c|}
\hline Native LOD (standard deviation, 2.5 ) & 3,68 & $\mathrm{pg} / \mathrm{ml}$ \\
\hline LLOQ (concentration CV, 20\%) & 6 & $\mathrm{pg} / \mathrm{ml}$ \\
\hline ULOQ (concentration CV, 20\%) & 50500 & $\mathrm{pg} / \mathrm{ml}$ \\
\hline Top concentration (at 15 AEB) & 30590,36 & $\mathrm{pg} / \mathrm{ml}$ \\
\hline Assay Range (pg/ml) & $\mathbf{6}$ & $\mathbf{3 0 5 9 0 , 3 6}$ \\
\hline
\end{tabular}

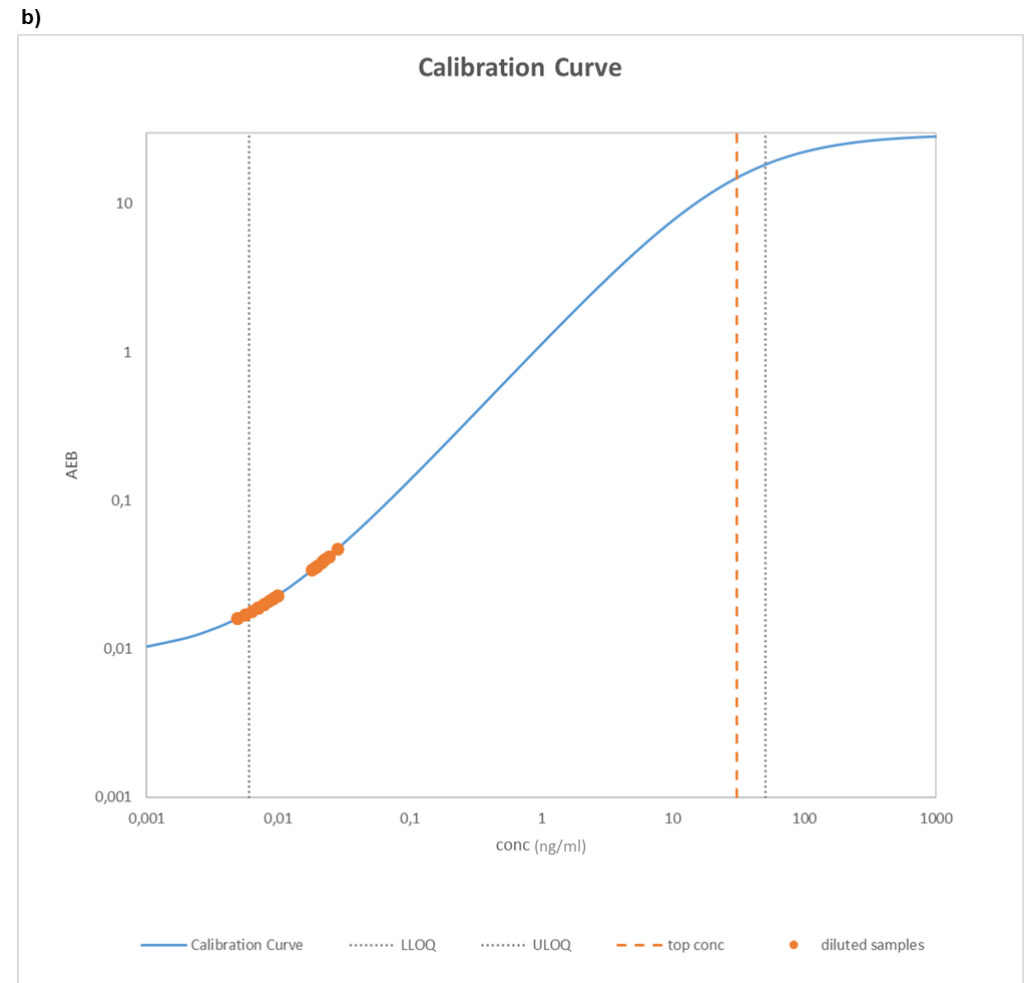


Supplementary Fig. S2: Receiver operating characteristic (ROC) curve for the levels of $\alpha$-syn PF in CSF of PD patients vs CT. AUC (area under the curve): 0.68 ; Sensitivity: $62.8 \%$ and Specificity: $67.7 \% . P=0.0097$.

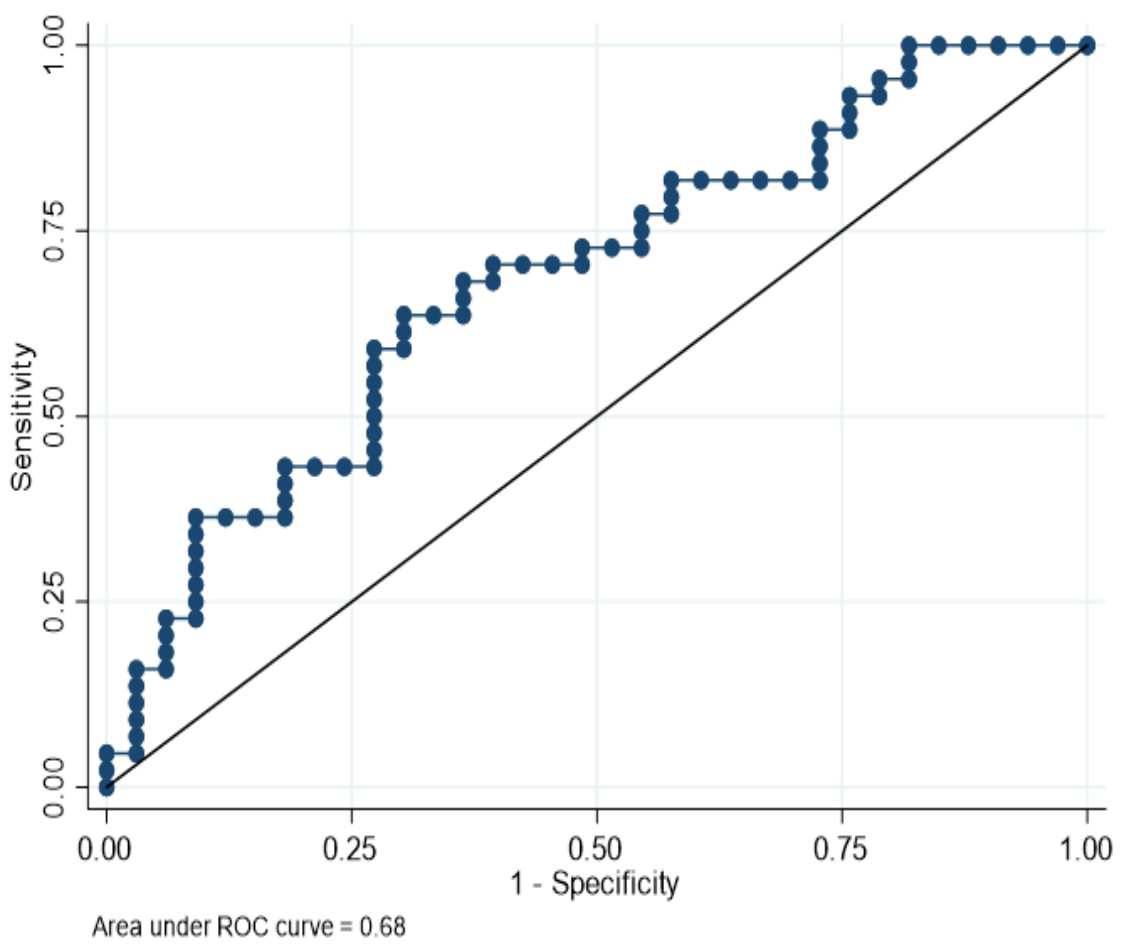

